\title{
Pengaruh Metode Pengolahan Terhadap Aktivitas Antioksidan Dan Karakteristik Teh Herbal Bubuk Daun Afrika (Vernonia amygdalina Delile)
}

\section{The Effect Of Processing Methods On Antioxidant Activity And Characteristics Of Tea Herbal Powder Of African Leaf (Vernonia amygdalina Delile)}

\author{
Karina Dinda Putri ${ }^{1}$, N.L. Ari Yusasrini ${ }^{1 *}$, K.A. Nocianitri ${ }^{1}$ \\ Program Studi Ilmu dan Teknologi Pangan, Fakultas Teknologi Pertanian, Universitas Udayana Kampus \\ Bukit Jimbaran, Badung-Bali \\ *Penulis korespondensi: N.L. Ari Yusasrini, Email: ariyusasrini@unud.ac.id
}

\begin{abstract}
This study aims to determine the effect of processing methods on antioxidant activity and characteristics of African leaf herbal tea and find out the right processing method to get the highest antioxidant activity and the best characteristics. The Completely Randomized Design was used in this study with treatment methods which consisted of 4 levels, namely Method A (steam blanching and drying), Method B (withering and pan firing) Method C (withering and Drying) and Method D (steam blanching and pan firing). This study was repeated 4 times to obtain 16 experimental units. The data obtained were analyzed by analysis of variance and if the treatment had a significant effect it was followed by Duncan's Multiple Range Test (DMRT). The parameters tested in this study include water content, ash content, total phenols, total flavonoids, color, antioxidant activity and sensory characteristics. The results showed that the methods of processing herbal tea powder of African leaves has a highly significant effect on water content, total phenol, total flavonoids, antioxidant activity, color, and sensory tests of color, taste, flavor and have a significant effect on overall reception and have no significant effect on ash content. Herbal tea powder of African leaves processed by method steaming and drying was the best treatment with a moisture content of $6.41 \%$, ash content of $5.27 \%$, total phenol of $2.4169 \mathrm{mgGAE} / \mathrm{g}$, total flavonoids $2,6563 \mathrm{mgQE} / \mathrm{g}$, antioxidant activity $67.28 \%$, color $(\mathrm{L}, \mathrm{a}, \mathrm{b}=4.86 ;-49.07 ; 34.71)$, light green color, very distinctive aroma of African tea leaves, very bitter taste, and overall reception likes.
\end{abstract}

Keywords : African tea, processing methods, antioxidant activity

\section{PENDAHULUAN}

Teh herbal merupakan istilah umum yang digunakan untuk minuman yang bukan berasal dari tanaman teh Camellia sinensis (Yudana, 2004). Teh herbal dapat dibuat dari kombinasi daun kering, biji, kayu, buah, bunga dan tanaman lain yang bermanfaat bagi kesehatan. Teh herbal memiliki khasiat yang beragam untuk membantu pengobatan suatu penyakit tergantung jenis teh herbal yang digunakan (Ravikumar, 2014).
Teh herbal dapat dibuat dari berbagai macam daun, salah satunya adalah daun afrika. Daun afrika banyak tumbuh di negara yang beriklim tropis salah satunya adalah Indonesia (Ibrahim, et al., 2004). Berdasarkan hasil penelitian Ijeh, et al., (2010) menyatakan bahwa daun afrika memiliki kandungan gizi antara lain adalah sebagai berikut: protein $13,2 \%$, serat $14,2 \%$, karbohidrat 29,3\%, lemak 4,7\%, kadar abu $10 \%$, kadar air 14\%, asam askorbat 166,5 mg/100 g, karotenoid 30 mg/100 g, kalsium 
0,97 g/ $100 \mathrm{~g}$, besi 7,5 mg/100 g, fosfor, dan selenium. Daun afrika juga mengandung saponin, koumarin, asam fenolat, lignan, xanton, terpen, peptida, dan luteolin, flavonoid, folifenol dan senyawa lainnya yang dapat mencegah berbagai penyakit yang berkaitan dengan stres oksidatif.

Salah satu cara yang paling mudah dan umum untuk mengkonsumsi daun afrika adalah dengan menjadikannya sebagai teh herbal. Menurut Preedy (2013), terdapat beberapa macam bentuk teh salah satunya berbentuk bubuk (ground powder). Meminum teh dalam bentuk bubuk dapat membantu kita mencerna senyawa-senyawa dalam teh yang tidak larut dalam air seperti berbagai vitamin larut lemak, serat makanan yang tidak larut air, klorofil, protein, dan lainlain. Teh biasanya diminum hanya dalam bentuk ekstrak sehingga seluruh senyawa yang tidak larut air terbuang (Preedy, 2013).

Kualitas teh dipengaruhi oleh beberapa faktor antara lain, letak (tinggi) kebun teh, sistem pemetikan, rotasi pemetikan serta metode pengolahan. Metode pengolahan yang berbeda dapat mempengaruhi karakteristik fisik teh dan air seduhannya, serta kandungan antioksidan teh tersebut. Proses pengolahan teh herbal bubuk secara umum mengacu pada pengolahan teh hijau, karena selama proses pengolahan teh hijau tidak dilakukan proses oksidasi enzimatis (fermentasi) yang menyebabkan warna merah kecoklatan pada teh. Proses oksidasi enzimatis akan menyebabkan perubahan senyawa katekin menjadi theaflavin dan thearubigin. Semakin banyak senyawa katekin yang diubah menjadi theflavin dan thearubigin maka aktivitas antioksidan teh akan menurun oleh karena itu penglahan teh hijau lebih dapat mempertahan aktivitas antioksidan teh. Menurut Kosinska dan Andlauer (2014), pengolahan teh hijau dibagi atas dua jenis yaitu teh hijau jepang dengan cara pengukusan dan teh hijau cina dengan cara penyangraian. Selain itu terdapat beberapa metode lain dalam pembuatan teh hijau yaitu dengan metode tradisional Indonesia dan metode Thailand dengan menggunakan pengukusan kemudian penyangraian.

Pengolahan teh hijau Jepang terbagi atas proses pengukusan (steaming), penggilingan atau pembentukan, dan pengeringan, sedangkan pengolahan teh hijau cina dikenal dengan proses penyangraian (pan firing) sebagai proses untuk menginaktifkan enzim. Teh hijau indonesia atau yang disebut dengan teh hijau tradisional adalah teh hijau yang diproses dengan pelayuaan pada suhu ruang dan pengeringan. Teh hijau thailand merupakan teh yeng proses pengolahannya adalah perpaduan antara teh hijau jepang dengan teh hijau cina yaitu adanya proses pengukusan dan penyangraian sebagai proses pengeringan.

Menurut penelitian Felicia (2016) menyatakan bahwa metode pengolahan sangat berpengaruh terhadap kadar total fenol, flavonoid dan aktivitas antioksidan teh 
herbal bubuk daun alpukat. Metode pengolahan juga mempengaruhi karakteristik sensoris warna, aroma, rasa serta penerimaan keseluruhan. Kadar fenol, flavonoid dan antioksidan lebih tinggi dihasilkan dari metode jepang dibandingkan dengan metode cina karena pada proses penyangraian pada metode cina asam-asam fenolik, senyawa flavonoid akan mengalami penurunan seiring dengan peningkatan suhu. Dari hasil penelitian tersebut menyatakan bahwa metode jepang lebih mampu untuk mempertahankan senyawa bioaktif yang terdapat pada bahan karena pada metode jepang menggunakan proses pengukusan. Pengukusan bertujuan untuk menonaktifkan enzim polifenoloksidase. Enzim polifenoloksidase merupakan kunci dalam pengolahan teh hijau. Dalam teh, inaktivasi enzim polifenol oksidase menghambat oksidasi senyawa katekin untuk membentuk theaflavin dan thearubigin (Turkamen, 2009). Karakteristik sensoris teh herbal bubuk daun alpukat yang diolah dengan metode jepang juga lebih disukai oleh panelis dibandingkan dengan teh herbal bubuk daun alpukat yang diolah dengan metode cina.

Menurut penelitian Laelasari (2016) aktivitas antioksidan teh herbal bubuk daun murbei dengan metode pengolahan Indonesia memiliki aktivitas antioksidan yang lebih tinggi dibandingkan dengan metode pengolahan Thailand dengan nilai IC50 55,59 ppm dan termasuk ke dalam golongan antioksidan potensi kuat. Pengolahan dengan metode thailand memiliki aktivitas antioksidan yang lebih rendah karena pada pengolahan dengan metode thailand proses yang dilakukan adalah dengan melakukan pengukusan dan penyangraian. Sehingga teh herbal bubuk daun murbei yang diolah dengan metode pengolahan thailand memiliki kondisi yang lebih basah dan warna produk yang lebih hitam. Metode pengolahan juga mempengaruhi karakteristik sensoris warna air seduhan teh herbal bubuk yang dihasilkan. Proses pengukusan bertujuan untuk melayukan daun dan mempertegas warna hijau. Tetapi dalam hal lain daun menjadi basah dan suhu tinggi yang dihasilkan dari pengukusan dapat memicu rusaknya polifenol yang terkandung dalam daun murbei. Selain itu penyangraian dengan suhu tinggi pun lebih memacu rusaknya polifenol yang ada.

Selama ini belum terdapat penelitian yang dilakukan untuk membandingkan keempat metode pengolahan tersebut terhadap aktivitas antioksidan dan karakteristik teh herbal bubuk daun afrika. Oleh karena itu, penelitian ini dilakukan untuk mengetahui apakah metode pengolahan berpengaruh terhadap aktivitas antioksidan dan karakteristik teh herbal bubuk daun afrika dan mengetahui metode pengolahan yang tepat sehingga menghasilkan teh herbal bubuk daun afrika dengan aktivitas antioksidan tertinggi dan karakteristik terbaik 


\section{METODE PENELITIAN}

\section{Tempat dan Waktu}

Penelitian ini dilakukan di laboratorium Pengolahan Pangan dan Analisis Pangan, Fakultas Teknologi Pertanian, Gedung Agrokomplek Universitas Udayana, Jalan Jendral Sudirman, Denpasar, Bali. Penelitian ini dilakukan pada bulan Januari - Februari 2020.

\section{Bahan dan Alat}

Bahan yang digunakan dalam penelitian ini adalah daun afrika muda yang memiliki warna hijau muda, pangkal daun membulat yang diambil 3 lembar di bawah pucuk yang diperoleh dari Jalan Kapten Japa no H 18, Denpasar Timur. Bahan kimia yang digunakan yaitu 2,2-difenil-1-pikrilhidrazil (DPPH) (Himedia), Folin-Ciocalteu (Merck), metanol pro analisis (PA), standar asam galat (Merck), $\mathrm{Na}_{2} \mathrm{CO}_{3}$ (Merck), $\mathrm{AlCl}_{3}$ (Merck), standar kuersetin (sigma) dan aluminium foil.

Alat yang digunakan dalam penelitian ini adalah kompor, wajan, ayakan 120 mesh, termometer, blender, gelas beaker, labu takar, cawan oven, gelas ukur, tabung reaksi, pipet mikro, pipet ukur, desikator, pinset, vortex, spektrofotometer (Genesys 10S UV-Vis), oven (Labo DO 225), timbangan analitik (Shimadzu ATY224), dan color reader (AccuProbe HH06), pengukus, sentrifius.

\section{Rancangan Penelitian}

Rancangan yang digunakan pada penelitian ini adalah Rancangan Acak Lengkap (RAL) dengan perlakuan metode pengolahan yang terdiri dari 4 taraf perlakuan yaitu metode A (Pengukusan dan Pengeringan), metode $\mathrm{B}$ (Pelayuan dan Penyangraian), metode $\mathrm{C}$ (Pelayuan dan Pengeringan) dan metode D (Pengukusan dan Penyangraian). Percobaan diulang sebanyak empat kali sehingga diperoleh 16 unit percobaan. Data yang diperoleh dianalisis dengan sidik ragam ANOVA dan apabila terdapat pengaruh perlakuan terhadap parameter objektif dan subjektif yang diamati, maka akan diuji lanjut dengan uji Duncan's Multiple Range Test (DMRT) dengan tingkat signifikansi $\mathrm{P}<0,05$ (Hamidah et al., 2014).

\section{Parameter yang Diamati}

Parameter yang diamati dalam penelitian ini meliputi kadar air (AOAC, 2005), kadar abu (AOAC, 2005), total fenol menggunakan metode folin-ciocalteu (Sakanaka et al., 2003), total flavonoid menggunakan metode spektrofotometri (Rahman et al., 2006), aktivitas antioksidan menggunakan metode DPPH (Blois, 1958 dalam Hanani et al., 2005), warna menggunakan metode colorimeter (Topuz et al., 2014), dan uji rangking karakteristik sensoris air seduhan teh berupa warna, aroma, rasa, serta uji hedonik penerimaan keseluruhan menggunakan metode yang dilakukan oleh Gromer (2009).

\section{Pelaksanaan Penelitian}

\section{Metode A (Pengukusan dan Pengeringan)}

Pengolahan teh herbal bubuk daun afrika dengan metode A dilakukan sesuai dengan yang dikerjakan oleh Topuz et al., 
(2014) yang dimodifikasi. Sebanyak 100 gram daun afrika segar dipisahkan batang dan tulang daunnya kemudian dikukus dengan suhu $100^{\circ} \mathrm{C}$ selama 90 detik dan diangkat serta didinginkan selama 5 menit, setelah itu daun dikeringkan dalam oven dengan suhu $95^{\circ} \mathrm{C}$ selama 30 menit, kemudian daun yang sudah kering selanjutnya dihaluskan menggunakan blender. Teh yang sudah dihaluskan kemudian diayak dengan ayakan 120 mesh.

\section{Metode B (Pelayuan dan Penyangraian)}

Pembuatan teh herbal bubuk daun afrika dengan metode B dilakukan sesuai dengan yang dikerjakan oleh Setyamidjaja, (2000) yang dimodifikasi. Sebanyak 100 gram daun afrika dilayukan selama 24 jam dengan cara diangin-anginkan pada ruang terbuka dengan suhu $28^{\circ} \mathrm{C}$. Setelah layu, dilakukan pemisahan batang dan tulang daun. Daun kemudian diletakkan di atas wajan dan disangrai selama 30 menit dengan suhu 100 ${ }^{\circ} \mathrm{C}$ sambil terus dibalik-balikan daunnya agar terkena panas secara merata, kemudian daun digiling hingga menjadi halus. Teh yang sudah dihaluskan selanjutnya diayak dengan ayakan 120 mesh.

\section{Metode C (Pelayuan dan Pengeringan)}

Pembuatan teh herbal bubuk daun afrika dengan metode $\mathrm{C}$ dilakukan sesuai dengan yang dikerjakan oleh Damayanthi et al., (2008) yang dimodifikasi. Sebanyak 100 gram daun afrika dilayukan selama 24 jam dengan cara diangin-anginkan pada ruang terbuka dengan suhu $28^{\circ} \mathrm{C}$. Setelah layu, dilakukan pemisahan batang dan tulang daun, lalu dikeringkan dalam oven dengan suhu $95^{\circ} \mathrm{C}$ selama 30 menit kemudian daun digiling hingga menjadi halus. Teh yang sudah dihaluskan selanjutnya diayak dengan ayakan 120 mesh.

\section{Metode D(Pengukusan dan Penyangraian)}

Pembuatan teh herbal bubuk daun afrika dengan metode D dilakukan sesuai dengan yang dikerjakan oleh Standar Nasional Thailand (2009) yang dimodifikasi Sebanyak 100 gram daun afrika yang sudah dipisahkan batang dan tulang daunnya, lalu dikukus dengan suhu $100^{\circ} \mathrm{C}$ selama 90 detik. Daun didinginkan selama 5 menit, lalu daun kemudian diletakkan di atas wajan dan disangrai selama 30 menit dengan suhu $100^{\circ} \mathrm{C}$, kemudian daun digiling hingga menjadi halus. Teh yang sudah dihaluskan selanjutnya diayak dengan ayakan 120 mesh.

\section{HASIL DAN PEMBAHASAN}

Nilai rata-rata kadar air, kadar abu, total fenol, total flavonoid, dan aktivitas antioksidan teh herbal bubuk daun afrika dapat dilihat pada Tabel 1.

\section{Kadar Air}

Hasil sidik ragam menunjukkan bahwa metode pengolahan berpengaruh sangat nyata $(\mathrm{P}<0,01)$ terhadap kadar air teh herbal bubuk daun afrika. Menurut Karina (2008) Menurunnya kadar air dalam bahan akibat dari proses penguapan. Makin tinggi suhu udara pengering, makin besar energi panas yang dibawa udara sehingga makin 
banyak jumlah massa cairan yang diuapkan dari permukaan bahan yang dikeringkan. Kemampuan bahan untuk melepaskan air dari permukaannya juga akan semakin besar dengan meningkatnya suhu udara pengering yang digunakan.

Tabel 1. Nilai rata-rata kadar air, kadar abu, total fenol, total flavonoid, dan aktivitas antioksidan teh herbal bubuk daun afrika

\begin{tabular}{cccccc}
\hline Perlakuan & $\begin{array}{c}\text { Kadar Air } \\
(\%)\end{array}$ & $\begin{array}{c}\text { Kadar Abu } \\
(\%)\end{array}$ & $\begin{array}{c}\text { Total fenol } \\
(\mathrm{mgGAE} / \mathrm{g})\end{array}$ & $\begin{array}{c}\text { Total } \\
\text { Flavonoid } \\
(\mathrm{mgQE} / \mathrm{g})\end{array}$ & $\begin{array}{c}\text { Aktivitas } \\
\text { Antioksidan } \\
(\%)\end{array}$ \\
\hline $\begin{array}{c}\text { Metode A } \\
\text { (pengukusan } \\
\text { dan }\end{array}$ & $6,41 \pm 0,07$ a & $5,27 \pm 0,06 \mathrm{a}$ & $2,4169 \pm 0,07 \mathrm{a}$ & $2,6563 \pm 0,01 \mathrm{a}$ & $67,28 \pm 0,65 \mathrm{a}$ \\
$\begin{array}{c}\text { pengeringan) } \\
\text { Metode B }\end{array}$ & $3,14 \pm 0,06 \mathrm{~d}$ & $5,23 \pm 0,04 \mathrm{a}$ & $1,1575 \pm 0,03 \mathrm{~d}$ & $1,6805 \pm 0,02 \mathrm{~d}$ & $31,13 \pm 0,30 \mathrm{~d}$ \\
$\begin{array}{c}\text { (pelayuan dan } \\
\text { penyangraian) }\end{array}$ & & & & & \\
$\begin{array}{c}\text { Metode C } \\
\text { (pelayuan dan } \\
\text { pengeringan) }\end{array}$ & $4,14 \pm 0,11 \mathrm{c}$ & $5,25 \pm 0,06 \mathrm{a}$ & $1,7327 \pm 0,08 \mathrm{~b}$ & $2,2640 \pm 0,02 \mathrm{~b}$ & $54,58 \pm 0,19 \mathrm{~b}$ \\
$\begin{array}{c}\text { Metode D } \\
\text { (pengukusan } \\
\text { dan }\end{array}$ & $5,17 \pm 0,03 \mathrm{~b}$ & $5,19 \pm 0,09 \mathrm{a}$ & $1,4943 \pm 0,05 \mathrm{c}$ & $1,9535 \pm 0,02 \mathrm{c}$ & $38,64 \pm 0,49 \mathrm{c}$ \\
$\begin{array}{c}\text { penyangraian) } \\
\text { Keterangan: Nilai rata }- \text { rata yang diikuti oleh huruf yang berbeda pada kolom yang sama menunjukkan } \\
\text { perlakuan yang berbeda nyata }(\mathrm{P}<0,05)\end{array}$ & & & & \\
\hline
\end{tabular}

Tabel 1 menunjukkan kadar air terendah terdapat pada metode B yaitu sebesar 3,14\%, sedangkan kadar air tertinggi terdapat pada metode A sebesar 6,41\%. Metode A (pengukusan dan pengeringan) memiliki kadar air yang paling tinggi dibandingkan dengan metode yang lain karena pada metode A dilakukan proses pengukusan serta pengeringan menggunakan oven yang suhunya lebih rendah yaitu $95^{\circ} \mathrm{C}$ selama 30 menit dibandingkan dengan suhu penyangraian yaitu $100^{\circ} \mathrm{C}$ selama 30 menit, hal ini juga dapat mempengaruhi kadar air pada bahan. Kemudian selama proses pengukusan terjadi kontak antara bahan dengan uap air yang menyebabkan bahan lebih basah dan meningkatkan kadar air yang terkandung dalam bahan.

Kadar air pada metode B (pelayuan dan penyangraian) merupakan kadar air paling rendah dibandingkan dengan metode lainnya, hal ini dikarenakan pada metode B dilakukan proses pelayuan selama 24 jam pada suhu ruang dan penyangraian. Proses penyangraian merupakan proses pengeringan 
menggunakan suhu tinggi yaitu $100^{\circ} \mathrm{C}$ selama 30 menit. Menurut Joko et al. (2009) menyatakan selama proses penyangraian terjadi perpindahan panas dari media penyangraian ke bahan pangan dan juga perpindahan massa air. Panas yang mengakibatkan terjadinya perubahan massa air dari bahan dikarenakan adanya panas laten penguapan. Perubahan massa air terjadi ketika kandungan air pada bahan telah sampai pada kondisi jenuh, sehingga menyebabkan kandungan air pada bahan berubah dari fase cair menjadi uap. Perubahan kadar air selama penyangraian menyebabkan penurunan kadar air pada teh herbal bubuk daun afrika. Rendahnya kadar air pada metode $\mathrm{B}$ juga dipengaruhi oleh perlakuan pendahuluan yaitu proses pelayuan. Proses pelayuan juga dapat menurunkan kadar air sebesar 55\%-70\% (Preedy, 2013).

Teh herbal bubuk daun afrika yang diolah dengan metode $\mathrm{C}$ (pelayuan dan pengeringan) memiliki kadar air yaitu sebesar 4,14\%. Hal ini dikarenakan pada metode $\mathrm{C}$ tedapat proses pelayuan pada suhu ruang selama 24 jam dan pengeringan menggunakan oven dengan suhu $95^{\circ} \mathrm{C}$ selama 30 menit. Proses pelayuan dapat menurunkan kadar air pada bahan. Menurut Putratama (2009) menyatakan bahwa selama proses pelayuan terjadi perubahan kimia seperti berkurangnya kandungan zat padat, berkurangnya pati dan gum, naiknya kadar gula, serta turunnya kadar air yang terdapat dalam bahan.

Kadar air teh herbal bubuk daun afrika yang diolah dengan metode $\mathrm{D}$ (pengukusan dan penyangraian) memiliki kadar air sebesar $5,17 \%$. Pada metode D dilakukan proses pengukusan dan penyangraian. Proses penyangraian dapat menurunkan kadar air lebih tinggi dibandingan dengan proses pengeringan menggunakan oven, namun pada metode $\mathrm{D}$ adanya proses pengukusan menyebabkan naiknya kadar air pada daun yang menyebabkan kadar air pada teh herbal bubuk daun afrika yang diolah dengan metode D lebih tinggi dibandingkan metode C. Berdasarkan SNI 3945:2016 kadar air pada produk teh herbal bubuk memiliki nilai maksimal adalah 8\%. Dengan demikian kadar air yang dimiliki teh herbal bubuk daun afrika dengan semua metode pengolahan memiliki kadar air yang masih termasuk dalam katagori kadar air teh herbal bubuk yang ditetapkan oleh SNI.

\section{Kadar Abu}

Hasil sidik ragam menunjukkan bahwa metode pengolahan berpengaruh tidak nyata $(\mathrm{P}>0,05)$ terhadap kadar abu teh herbal bubuk daun afrika. Kadar abu merupakan parameter untuk menunjukkan nilai kandungan bahan anorganik (mineral) yang ada di dalam suatu bahan atau produk. Semakin tinggi nilai kadar abu maka semakin banyak kandungan bahan anorganik di dalam produk tersebut. Komponen bahan anorganik di dalam suatu bahan sangat bervariasi baik jenis maupun 
jumlahnya (Roni, 2008). Kadar abu yang terdapat pada teh herbal bubuk daun afrika menunjukkan adanya perbedaan yang tidak signifikan antar perlakuan. Kadar abu pada teh herbal bubuk daun afrika berkisar antara 5,27 hingga 5,19\%. Namun keempat metode tersebut tidak memberikan pengaruh nyata terhadap kadar abu teh herbal bubuk daun afrika yang dihasilkan. Hal ini diduga bahwa metode pengolahan yang diberikan tidak menyebabkan keluarnya mineral dari daun afrika. Besarnya penurunan kadar abu tergantung proses pengolahan, suhu pengolahan dan luas permukaan produk. Mineral tidak mudah rusak karena proses pengolahan namun pengolahan dapat menyebabkan penyusutan mineral maksimal 3\% (Roni, 2008). Hal tersebut juga dikemukakan oleh Sayuti (2010) pada penelitiannya bahwa tidak ada perubahan terhadap kadar abu akibat pengolahan pada daun murbei karena jumlah mineral tidak berubah selama diberi perlakuan pelayuan dan pengeringan. Hal tersebut juga dinyatakan dalam Liliana (2005), bahwa lama pelayuan daan pengeringan daun seledri tidak berpengaruh nyata terhadap kadar abu, dikarenakan pelayuan dan pengeringan tersebut tidak menyebabkan keluarnya sebagian besar padatan terlarut (mineral) dari dalam sel daun. Kadar abu teh herbal bubuk daun afrika dengan keempat metode sudah sesuai dengan SNI yaitu 4-8\%.

\section{Total Fenol}

Hasil sidik ragam menunjukkan bahwa metode pengolahan berpengaruh sangat nyata $(\mathrm{P}<0,01)$ terhadap total fenol teh herbal bubuk daun afrika. Pada Tabel 1 menunjukkan metode pengolahan yang menghasilkan total fenol tertinggi terdapat pada metode A sebesar 2,4169 mgGAE/g, sedangkan kadar total fenol terendah yaitu pada metode B sebesar 1,1579 mgGAE/g.

Total fenol teh herbal bubuk yang diolah dengan metode A (pengukusan dan pengeringa) lebih tinggi dibandingkan metode lainnya hal ini dikarenakan pada metode A dilakukan proses pendahuluan yaitu pengukusan serta pengeringan menggunakan oven. Pengukusan atau steam blanching merupakan suatu perlakuan pemanasan dengan menggunakan uap panas dengan suhu $100^{\circ} \mathrm{C}$ selama 90 detik. Menurut Pujianingsih et al., (2010), menyatakan bahwa secara umum pengukusan bertujuan untuk menonaktifkan enzim polifenoloksidase. Enzim polifenoloksidase merupakan kunci dalam pengolahan teh hijau. Dalam teh, inaktivasi enzim polifenol oksidase menghambat oksidasi senyawa katekin untuk membentuk theaflavin dan thearubigin (Turkamen, 2009). Semakin banyak senyawa yang diubah menjadi theaflavin dan thearubigin maka senyawa fenol yang terkandung dalam teh akan semakin menurun. Menurut Réblová (2012), asam-asam fenolik akan menunjukkan penurunan seiring dengan meningkatnya 
suhu. Senyawa fenol dapat teroksidasi karena adanya panas, oksigen, dan aktivitas enzim polifenol oksidase sehingga membentuk radikal ortosemiquinon yang bersifat reaktif dan dapat bereaksi lebih lanjut dengan senyawa amino membentuk produk berwarna coklat dengan berat molekul tinggi (Manohan dan Wai, 2012).

Teh herbal bubuk daun afrika dengan metode A (pengukusan dan pengeringan) juga menggunakan oven sebagai metode pengeringan. Menurut Bernard et al. (2014), bahwa total fenol yang dihasilkan melalui metode pengeringan dengan oven lebih tinggi dibandingkan dengan pengeringan dengan sinar matahari dan dikeringkan dengan penyangraian. Hal ini dapat disebabkan oleh inaktivasi enzim yang berlangsung lebih cepat. Menurut Bennett, et al., (2011) melaporkan bahwa fenolik pada buah-buahan dan sayur-sayuran rentan terhadap degradasi oksidatif oleh polifenol oksidase selama pengeringan yang mengakibatkan reaksi kondensasi intermolekul dan kadarnya menurun. Pengeringan dengan oven menggunakan suhu yang lebih tinggi dari pengeringan dengan sinar matahari dan kering angin serta dalam waktu yang lebih singkat akan mempercepat proses inaktivasi enzim polifenol oksidase sehingga kadar total fenolik menjadi lebih tinggi (Bernard et al., 2014). Chan et al. (2009) juga melaporkan bahwa kehilangan total fenolik pada proses pengeringan daun kunyit menggunakan oven lebih rendah dibandingkan dengan pengeringan dengan sinar matahari dan penyangraian.

Teh herbal bubuk daun afrika yang diolah dengan menggunakan metode $\mathrm{B}$ (pelayuan dan penyangraian) memiliki total fenol yang lebih rendah dibandingkan dengan metode yang lainnya. Pada metode B dilakukan proses pelayuan pada suhu ruang selama 24 jam dan penyangraian pada suhu $100^{\circ} \mathrm{C}$ selama 30 menit. Proses pelayuan dapat mempengaruhi total fenol, semakin lama waktu pelayuan yang dilakukan maka total fenol yang terkandung semakin menurun. Selama pelayuan daun teh sudah mengalami proses oksidasi enzimatis, oleh karena itu semakin lama proses pelayuan maka semakin banyak komponen katekin yang diubah menjadi theaflavin dan thearubigin. Pada metode B juga dilakukan pengeringan dengan cara penyangraian. Proses penyangraian menggunakan suhu yang lebih tinggi yaitu $100^{\circ} \mathrm{C}$ selama 30 menit dibandingan pengeringan menggunakan oven yang hanya menggunakan suhu $95^{\circ} \mathrm{C}$ selama 30 menit. Semakin meningkatnya suhu pengeringan yang digunakan menyebabkan total fenol teh daun afrika semakin menurun. Hal ini terjadi karena panas dapat menyebabkan terjadinya kerusakan terhadap komponen penyusun daun. Keruskan ini dapat menyebabkan keluarnya senyawa polifenol dari dalam daun yang menyebabkan komponen fenol dalam daun semakin rendah (Chu dan Juneja, 1997). Menurut Susanti (2008), semakin tinggi suhu 
pengeringan mengakibatkan peningkatan proses inaktivasi enzim polifenol oksidase, sehingga aktivitas enzim akan semakin rendah dan kerusakan senyawa polifenol semakin sedikit, namun jika suhu pengeringan melampaui suhu optimum, maka stabilitas senyawa polifenol akan terganggu sehingga menyebabkan penurunan kandungan senyawa polifenol pada bahan.

Total fenol teh herbal bubuk daun afrika yang diolah dengan metode $\mathrm{C}$ (pelayuan dan pengeringan) sebesar 1,7327 $\mathrm{mgGEA} / \mathrm{g}$. Pengolahan teh dengan metode $\mathrm{C}$ hampir sama dengan metode A namun yang membedakan adalah proses pengeringannya. Proses pengeringan pada metode $\mathrm{C}$ menggunakan oven sehingga total fenol yang terkandung lebih tinggi dibandingkan dengan metode $\mathrm{B}$.

Teh herbal yang diolah menggunakan metode D memiliki total fenol yang lebih rendah dibandingkan metode $\mathrm{C}$ namun lebih tinggi dibandingkan dengan metode $\mathrm{B}$ yaitu sebesar 1,4943 mgGAE/g. pada dasarnya prinsip metode $\mathrm{D}$ hampir sama dengan metode A yaitu adanya proses pengukusan dan yang membedakan adalah proses pengeringannya dengan cara sangrai sehingga total fenol yang dihasilkan lebih rendah dibandingkan dengan metode $\mathrm{A}$.

\section{Total Flavonoid}

Hasil sidik ragam menunjukkan bahwa metode pengolahan berpengaruh sangat nyata $(\mathrm{P}<0,01)$ terhadap total flavonoid teh herbal bubuk daun afrika. Dari
Tabel 1 menunjukkan total flavonoid yang terendah yaitu pada metode B sebesar 1,6806 $\mathrm{mgQE} / \mathrm{g}$ dibandingkan dengan metode yang lainnya dan kadar total flavonoid tertinggi terdapat pada metode A dengan total flavonoid sebesar 2,6563 mgQE/g.

Total flavonoid pada teh herbal bubuk daun afrika yang diolah dengan metode $\mathrm{A}$ (pengukusan dan pengeringan) lebih tinggi dibandingkan dengan metode lainnya hal ini dikarenakan adanya proses pengukusan dan pengeringan menggunakan oven. Proses pengukusan merupakan salah satu pemanasan secara basah. Pengolahan dengan pemanasan basah selama satu menit tidak mempengaruhi senyawa fitokimia dan integritas struktur sel yang akan mengakibatkan migrasi komponen sehingga menyebabkan kerugian akibat kerusakan melalui berbagai reaksi kimia yang melibatkan enzim, cahaya dan oksigen (Zainol et al., 2009). Menurut Roy (2007) proses pengukusan atau pemanasan microwave satu menit tidak menyebabkan perbedaan kandungan total flavonoid dengan daun kenikir segar karena tidak terjadinya kontak langsung antara daun dengan air sehingga tidak larutnya senyawa flavonoid kedalam air.

Total flavonoid teh herbal bubuk daun afrika yang diolah dengan metode $\mathrm{B}$ (pelayuan dan penyangraian) lebih rendah dibandingkan dengan metode lainnya. Hal ini disebabkan adanya proses pelayuan dan penyangraian pada metode $\mathrm{B}$. Pada proses 
pelayuan akan terjadi peningkatan atau penurunan komponen tertentu yang diinginkan dan yang tidak diinginkan. Menurut Arpah dalam Sayekti (2016), proses pelayuan akan meningkatkan atau menurunkan komponen tertentu yang diinginkan dan tidak diinginkan, karena suhu dalam pelayuan tidak optimal pada proses pelayuan. Menurut Pramono (2006), Jika dalam bahan kadar air masih tinggi dapat mendorong enzim melakukan aktivitasnya mengubah kandungan kimia yang ada didalam bahan menjadi produk lain. Perlakuan pemanasan pada bahan dapat menyebabkan keluarnya beberapa senyawa fenolik dengan berat molekul rendah, dimana flavonoid yang terdapat pada teh merupakan senyawa fenolik yang memiliki berat molekul rendah (Jeong et al., 2004)

Teh herbal bubuk yang diolah dengan metode C (pelayuan dan pengeringan) memiliki total fenol sebesar $1,7327 \mathrm{mgQE} / \mathrm{g}$. Pada metode $\mathrm{C}$ terdapat proses pelayuan dan pengeringan menggunakan oven dengan suhu $95^{\circ} \mathrm{C}$ selama 30 menit. Proses pengeringan pada daun teh herbal dapat menghancurkan lapisan lilin yang ada di permukaan luar daun dan selanjutnya akan memecah dinding sel sehingga akan memudahkan senyawa flavonoid untuk berdifusi ke dalam pelarut (Setyopratomo, 2014). Semakin tinggi suhu pengeringan menyebabkan semakin tinggi pula kerusakan terhadap dinding sel, sehingga semakin banyak senyawa flavonoid yang keluar. Sementara itu, pengaruh metode pengolahan terhadap total flavonoid juga dilaporkan oleh Bernard et al. (2014), bahwa total flavonoid yang dihasilkan melalui metode pengeringan oven dengan suhu $95^{\circ} \mathrm{C}$ selama 30 menit lebih tinggi dibandingkan dengan pengeringan dengan sinar matahari dengan suhu $29-30^{\circ} \mathrm{C}$ dan sangrai dengan suhu $100^{\circ} \mathrm{C}$ selama 30 menit.

Teh herbal bubuk yang diolah dengan metode D (pengukusan dan penyangraian) memiliki total flavonoid sebesar 1,4943 $\mathrm{mgQE} / \mathrm{g}$. Pada metode D terdapat proses pengukusan dan penyangraian dengan suhu $100^{\circ} \mathrm{C}$ selama 30 menit. Menurut Lenny (2006), senyawa flavonoid bersifat tidak tahan panas dan mudah teroksidasi pada suhu yang tinggi. Flavonoid menunjukkan sensitivitas yang berbeda dalam perlakuan panas tergantung pada strukturnya (Irina dan Mohamed, 2012). Bagaimanapun strukturnya, flavonoid akan terdegradasi pada suhu di atas $100^{\circ} \mathrm{C}$. Pengeringan dengan penyangraian dapat mendegradasi total flavonoid pada sampel (Bernard et al., 2014). Degradasi ini disebabkan oleh adanya kontak langsung antara daun afrika dengan sumber panas yang lama dan intensif sehingga terjadi degradasi enzimatis senyawa fitokimia. Chan et al. (2009) melaporkan bahwa reduksi total fenolik dapat terjadi karena reaksi enzimatis selama proses pengeringan. Suhu yang lebih tinggi seperti $100^{\circ} \mathrm{C}$ akan mengakibatkan penurunan kadar total flavonoid sementara itu suhu yang lebih rendah yaitu $80^{\circ} \mathrm{C}$ belum optimal untuk menginaktifkan enzim 
polifenolase sehingga kadar total flavonoid yang dihasilkan lebih rendah. Semakin tinggi suhu dan semakin lama waktu pemanasan maka aktivitasnya akan semakin menurun. Hal ini disebabkan oleh perubahan struktur tersier pada suhu tinggi (Zhang and Shao, 2015). Penurunan makromolekul seperti flavonoid selama pemanasan dipengaruhi oleh suhu dan waktu yang digunakan.

\section{Aktivitas Antioksidan}

Hasil sidik ragam menunjukkan bahwa metode pengolahan berpengaruh sangat nyata $(\mathrm{P}<0,01)$ terhadap aktivitas antioksidan teh herbal bubuk daun afrika. Antioksidan merupakan senyawa yang memberikan elektron atau reduktan, sehingga reaksi radikal bebas dapat dihambat. Senyawa ini memiliki berat molekul yang kecil, tetapi mampu menginaktivasi berkembangnya reaksi oksidasi dengan cara mencegah terbentuknya radikal. Antioksidan juga merupakan senyawa yang dapat menghambat reaksi oksidasi dengan mengikat radikal bebas dan molekul yang sangat reaktif (Winarsi, 2007). Antioksidan sangat dibutuhkan tubuh untuk menangkal radikal bebas dan pencegahan berbagai penyakit. Senyawa antioksidan memiliki kemampuan untuk berikatan dengan senyawa metabolit lain seperti protein, lemak, dan karbohidrat membentuk senyawa kompleks yang stabil sehingga menghambat mutagenesis dan karsinogenesis (Mukhopadiay, 2000 dalam Kasih, 2007).
Dari Tabel 1 menunjukkan teh yang diolah dengan metode A memiliki aktivitas antioksidan tertinggi dibandingkan dengan metode lainnya yaitu sebesar $67,28 \%$ dan aktivitas antioksidan terendah terdapat pada teh yang diolah dengan metode $\mathrm{B}$ yaitu sebesar $31,13 \%$.

Aktivitas antioksidan teh herbal bubuk yang diolah dengan metode A (pengukusan dan pengeringan) menghasilkan nilai antioksidan yang lebih tinggi dibandingkan dengan metode lainnya hal ini dikarenakan adanya proses pengukusan dan pengeringan menggunakan oven. Pada metode A. Proses pengukusan juga berpengaruh terhadap aktivitas antioksidan teh yang dihasilkan karena menurut Pujianingsih et al., (2010), menyatakan bahwa secara umum pengukusan bertujuan untuk menonaktifkan enzim polifenoloksidase. Beberapa hasil penelitian menunjukkan bahwa pengukusan bahan hasil pertanian dapat meningkatkan aktivitas antioksidan. Puuponen (2003) melaporkan bahwa aktivitas antioksidan kubis meningkat 9\% dibandingkan tanpa pengukusan. Pengukusan gandum setelah pemanenan pada suhu $100^{\circ} \mathrm{C}$ menunjukkan peningkatan antitioksidan tepung gandung (Cheng, 2006).

Teh herbal bubuk daun afrika yang diolah dengan metode B (Pelayuan dan penyangraian) memiliki aktivitas antioksidan yang paling rendah dibandingkan dengan metode lainnya. Pada metode B terdapat proses pelayuan dan penyangraian. Suhu merupakan salah satu faktor yang paling 
penting yang mempengaruhi aktivitas antioksidan. Umumnya, pemanasan menyebabkan percepatan reaksi inisiasi dan penurunan aktivitas antioksidan. Menurut Winarno (2002), proses pengeringan dengan suhu yang lebih tinggi seperti penyangraian mengakibatkan rusaknya zat aktif yang terkandung dalam suatu bahan pangan. Selain itu rendahnya aktivitas antioksidan pada metode B juga disebabkan oleh adanya proses pendahuluan yaitu pelayuan. Semakin lama waktu pelayuan menunjukkan aktivitas antioksidan yang semakin menurun, diduga hal tersebut terjadi akibat adanya sumber senyawa antioksidan yang hilang selama proses pelayuan, dan adanya perubahan kimia yang dialami oleh sumber antioksidan (Kusumaningrum, 2013). Selama proses pelayuan juga terjadi oksidasi polifenol oleh oksigen dari udara dengan bantuan enzim oksidase (Nasution dan Wachyuddin, 1975). Hal tersebut dikemukakan juga oleh Arpah (1993), bahwa pada proses pelayuan ini terjadi peningkatan atau penurunan komponen tertentu yang diinginkan dan komponen yang tidak diinginkan.

Aktivitas antioksidan teh herbal bubuk daun afrika yang diolah dengan metode $\mathrm{C}$ (pelayuan dan pengeringan) yaitu sebesar $54,58 \%$. Pada dasarnya pengolahan teh herbal bubuk dengan metode $\mathrm{C}$ hampir sama dengan metode $B$ yaitu adanya proses pelayuan namun yang membedakan adalah proses pengeringannya yang menggunakan oven sehingga aktivitas antioksidan teh yang diolah dengan metode $\mathrm{C}$ lebih tinggi dibandingkan dengan metode $\mathrm{B}$. Menurut Bernard et al. (2014), bahwa aktivitas antioksidan yang dihasilkan melalui metode pengeringan oven dengan suhu $95^{\circ} \mathrm{C}$ selama 30 menit lebih tinggi dibandingkan dengan pengeringan dengan sinar matahari dengan suhu $29-30^{\circ} \mathrm{C}$ dan sangrai dengan suhu $100^{\circ} \mathrm{C}$ selama 30 menit.

Teh herbal bubuk daun afrika yang diolah dengan metode $\mathrm{D}$ memiliki aktivitas antioksidan yaitu sebesar 38,64\%. Pada metode D terdapat proses pengukusan yang dapat meningkatkan aktivitas antioksidan pada teh herbal bubuk daun afrika namun yang menyebabkan nilai aktivitas antioksidan teh herbal bubuk yang diolah dengan metode D lebih rendah adalah proses pengeringannya dengan cara penyangraian, sehingga aktivitas antioksidan semakin menurun karena pada proses penyangraian terjadi kontak langsung antara sumber panas dengan bahan yang menyebabkan bahan kehilangan banyak komponen kimia yang bersifat sebagai antioksidan.

Tingginya aktivitas antioksidan teh herbal bubuk daun afrika juga dipengaruhi kadar total fenol dan flavonoid. Dalam penelitian ini dapat dilihat bahwa kandungan fenol dan flavonoid teh herbal bubuk yang diolah dengan metode A memiliki total fenol dan flavonoid yang lebih tinggi dibandingkan dengan metode yang lainnya. Aktivitas antioksidan meningkat seiring dengan meningkatnya kadar total fenol dan flavonoid 
yang merupakan senyawa bioaktif yang berperan sebagai antioksidan (Yondra et al., 2014). Kapasitas menangkap radikal bebas DPPH sebagian besar terkait dengan gugus hidroksil dari senyawa fenolik (Nakiboglu et al., 2007). Hal ini sesuai dengan data yang diperoleh bahwa semakin tinggi total fenol dan total flavonoid maka semakin tinggi pula aktivitas antioksidan. Senyawa yang memiliki aktivitas antioksidan adalah senyawa fenol yang mempunyai gugus hidroksi yang tersubstitusi pada posisi orto dan para terhadap $\mathrm{OH}$ dan -OR (Marjoni et al., 2015).

\section{Warna}

Hasil sidik ragam menunjukkan bahwa metode pengolahan berpengaruh sangat nyata $(\mathrm{P}<0,01)$ terhadap warna air seduhan teh herbal bubuk daun afrika. Nilai rata-rata warna air seduhan teh herbal bubuk daun afrika dapat dilihat pada Tabel 2.

\section{Tabel 2. Nilai rata-rata warna air seduhan teh herbal bubuk daun afrika}

\begin{tabular}{lccc}
\hline \multicolumn{1}{c}{ Perlakuan } & Nilai $L$ & Nilai $a$ & Nilai $b$ \\
\hline Metode A (Pengukusan dan Pengeringan) & $4.86 \pm 0,03 \mathrm{a}$ & $-49.07 \pm 0,46 \mathrm{a}$ & $34.71 \pm 0,24 \mathrm{~d}$ \\
Metode B (Pelayuan dan Penyangraian) & $4.29 \pm 0,04 \mathrm{~d}$ & $-38.51 \pm 1,01 \mathrm{~d}$ & $38.11 \pm 0,36 \mathrm{a}$ \\
Metode C (Pelayuan dan Pengeringan) & $4.62 \pm 0,05 \mathrm{~b}$ & $-45.83 \pm 0,94 \mathrm{~b}$ & $35.91 \pm 0,14 \mathrm{c}$ \\
Metode D (Pengukusan dan Penyangraian) & $4.45 \pm 0,05 \mathrm{c}$ & $-42.82 \pm 1,12 \mathrm{c}$ & $37.09 \pm 0,19 \mathrm{~b}$ \\
\hline
\end{tabular}

Keterangan : Nilai rata-rata yang diikuti oleh huruf yang berbeda pada kolom yang sama menunjukkan perlakuan yang berbeda nyata $(\mathrm{P}<0,05)$

$\mathrm{L}=$ Parameter kecerahan (Nilai $\mathrm{L}=0$ (hitam), $\mathrm{L}=100$ (putih))

$\mathrm{a}=$ Koordinat warna merah hingga hijau (Nilai $\mathrm{a}=+60$ (merah), $\mathrm{a}=-60$ (hijau))

$\mathrm{b}=$ Koordinat warna kuning hingga biru (Nilai $\mathrm{b}=+60$ (kuning), $\mathrm{b}=-60$ (biru))

Warna merupakan sifat sensoris pertama yang diamati pada saat konsumen melihat produk pangan. Salah satu faktor penentu mutu bahan makanan adalah warna. Warna makanan dapat dijadikan indikator mutu suatu produk. Menurut Desrosier (1969), warna bahan pangan dipengaruhi oleh kondisi permukaan bahan pangan dan kemampuannya untuk memantulkan, menyebarkan, menyerap dan meneruskan sinar yang nampak. Nilai lightness menunjukkan gelap terangnya (kecerahan) suatu warna (Winarno, 2004). Menurut Hutching (1999), notasi L menyatakan parameter kecerahan (lightness) yang mempunyai nilai 0 (hitam) sampai dengan 100 (putih). Notasi a adalah koordinat warna merah sampai hijau yang mempunyai nilai +60 (merah) dan -60 (hijau) maka semakin minus nilai a maka warna air seduhan teh semakin hijau. Notasi b menunjukkan warna kuning hingga biru dimana +60 (kuning) dan -60 (biru), maka semakin positif nilai b maka warna air seduhan semakin kuning.

Pada Tabel 2 dapat dilihat bahwa metode A memiliki kecerahan yang paling tinggi dengan nilai $(\mathrm{L}, \mathrm{a}, \mathrm{b}=4,86 ;-49,07$; 34,71 ), dan nilai kecerahan warna air seduhan terendah adalah metode $\mathrm{B}$ dengan nilai $(\mathrm{L}, \mathrm{a}$, $\mathrm{b}=4,29,-38,51,38,11)$. Metode $\mathrm{A}$ menghasilkan air seduhan yang berwarna lebih hijau yang ditunjukkan oleh nilai a yang 


\section{Warna}

Berdasarkan uji Friedman bahwa perlakuan metode pengolahan berpengaruh nyata $(\mathrm{P}<0,05)$ terhadap warna air seduhan teh herbal bubuk daun afrika. Warna air seduhan teh herbal bubuk daun afrika rata-rata berkisar antara 1,08 hingga 3,92. Dari keempat metode tersebut menghasilkan warna air seduhan teh yang berbeda. Warna air seduhan teh herbal bubuk daun afrika yang dioalah dengan metode A menghasilkan warna yang lebih hijau karena adanya proses pengukusan dan pengeringan. Menurut Yulianto et al. (2006), keuntungan dari proses pengukusan ialah dihasilkannya warna teh yang lebih kehijauan dan warna air seduhan yang lebih terang (hijau kekuningan). Sedangkan pada teh yang diolah dengan metode B dilakukan proses pelayuan dan penyangraian. Proses penyangraian juga dapat mempengaruhi warna air seduhan pada teh herbal bubuk karena selama proses penyangraian terjadi kontak langsung antara bahan dengan sumber panas yang menyebabkan warna teh yang dihasilkan lebih kecoklatan.

Warna air teh seduhan yang diolah dengan metode $\mathrm{C}$ menghasilkan warna hijau tua hal ini dikarenakan adanya proses pelayuan dan pengeringan. Proses pelayuan menyebabkan terhambatnya proses oksidasi enzimatis yang akan menyebabkan perubahan warna menjadi merah kecoklatan (Putratama 2009).

Warna air seduhan teh yang diolah dengan metode D menghasilkan warna hijau kecokltan. Warna ini disebabkan adanya proses pengukusan dan penyangraian. Proses pengukusan dapat memperbaiki warna daun teh menjadi lebih hijau namun pada proses penyangraian. Penyangraian merupakan proses pengeringan menggunakan suhu tinggi yaitu $100^{\circ} \mathrm{C}$ selama 30 menit. menurut Fitrayana (2014) menyatakan bahwa semakin tinggu suhu pengeringan yang digunakan dapat menyebabkan menurunnya warna alami teh herbal yang dihasilkan, hal ini disebabkan pada proses pengeringan yang merusak warna seperti klorofil pada daun. Menurut Winarno (2004) warna merupakan komponen penting dalam menentukan penerimaan suatu produk oleh konsumen karena tampilan visual pertama selain beberapa faktor antara lain cita rasa, aroma dan nilai gizinya.

\section{Aroma}

Berdasarkan uji Friedman bahwa perlakuan metode pengolahan berpengaruh nyata $(\mathrm{p}<0,05)$ terhadap bahwa aroma air seduhan teh herbal bubuk daun afrika. Aroma air seduhan teh herbal bubuk daun afrika ratarata berkisar antara 1,12 hingga 3,88. Dari keempat metode tersebut menghasilkan aroma teh herbal yang berbeda.

Metode A (pengukusan dan pengeringan) menghasilkan aroma sangat khas teh daun afrika. Aroma ini dipengaruhi karena adanya proses pengukusan dan pengeringan. Proses pengukusan pada metode A menyebabkan enzim polifenoloksidase menjadi inaktif, karena enzim polifenol 
oksidase menyebabkan perubahan aroma serta rasa pada teh (Pujianingsih, et al. 2010).

Metode B (pelayuan dan penyangraian) mengasilkan aroma yang tidak khas daun afrika karena adanya proses pelayuan dan penyangraian. Proses penyangraian yang menggunakan suhu tinggi serta bahan yang kontak langsung dengan panas membuat aroma teh herbal yang dihasilkan sedikit berbau gosong. Penggunaan suhu tinggi yang berlebihan akan menghanguskan dan mengeringkan daun dan memberikan bau asap. Meilgaard et al (2000) menyatakan bahwa aroma makanan timbul karena adanya komponen senyawa volatile yang mudah menguap namun komponen volatile akan hilang selama proses pemanasan.

Aroma air seduhan teh herbal bubuk yang diolah dengan metode $\mathrm{C}$ (pelayuan dan pengeringan) adalah aroma khas teh daun afrika. Menurunnya aroma teh herbal bubuk daun afrika yang diolah dengan metode $\mathrm{C}$ disebabkan adanya aktivitas enzim pada proses pelayuan dan pengeringan yang menyebabkan terlepasnya berbagai senyawa volatile pada bahan sehingga menimbulkan aroma khas pada teh herbal bubuk daun afrika semakin menurun.

Aroma air seduhan teh herbal yang diolah dengan metode $\mathrm{D}$ (pengukusan dan penyangraian) menghasilkan aroma agak khas teh daun afrika. Hal ini karena adanya proses pengukusan dan penyangraian. Semakin tinggi suhu pengeringan yang digunakan maka aroma dari teh herbal bubuk daun afrika akan semakin menurun. Hal ini disebabkan karena rusaknya senyawa-senyawa aromatik yang pada proses pengeringan (Meilgaard et al. 2000).

\section{Rasa}

Berdasarkan uji Friedman bahwa perlakuan metode pengolahan berpengaruh nyata $(p<0,05)$ terhadap rasa air seduhan teh herbal daun afrika. Rasa air seduhan teh herbal bubuk daun afrika rata-rata berkisar antara 1,24 hingga 3,84. Dari keempat metode tersebut menghasilkan rasa teh herbal dengan tingkat kepahitan yang berbeda. Rasa merupakan aspek penting dalam penilaian dalam suatu produk. Penilain rasa dilakukan oleh indera pengecap manusia ketika makananan atau minuman dikonsumsi (Meilgaard et al., 2000). Teh herbal yang diolah menggunakan metode A menghasilkan rasa sangat pahit, kemudian teh yang diolah dengan metode $B$ menghasilkan rasa agak pahit dan rasa teh dengan metode $\mathrm{C}$ adalah pahit, serta teh herbal yang diolah menggunakan metode $\mathrm{D}$ menghasilkan rasa yang tidak pahit. Rasa pahit yang terdapat pada air seduhan teh herbal bubuk daun afrika dipengaruhi adanya senyawa fenol dan flavonoid. Menurut Roni (2008), menyatakan bahwa senyawa fenol dan flavonoid dapat memberikan rasa pahit dan sepat pada seduhan teh sehingga semakin tinggi kandungan fenol dan flavonoid pada daun afrika maka rasa dari teh tersebut akan semakin sepat dan pahit. Namun semakin tinggi suhu pengeringan komponen yang menyebabkan rasa pahit pada teh seperti 
flavonoid akan semakin menurun. Penyangraian adalah proses pengeringan yang menggunakan suhu tinggi sehingga kandungan senyawa yang menimbulkan rasa pahit menurun (Mahmood et al., 2010). Menurut Preedy (2013) Penyangraian menghasilkan produk teh yang menghasilkan rasa yang lebih baik dibandingkan dengan teh yang dikeringkan di bawah sinar matahari (Preedy, 2013).

\section{Penerimaan Keseluruhan}

Analisis ragam menunjukkan bahwa perlakuan metode pengolahan berpengaruh nyata $\quad(\mathrm{p}<0,05) \quad$ terhadap penerimaan keseluruhan air seduhan teh herbal bubuk daun afrika. Nilai rata-rata uji hedonik penerimaan keseluruhan dapat dilihat pada Tabel 3 . Penilaian terhadap penerimaan keseluruhan menunjukkan bahwa nilai rata-rata yang diberikan oleh panelis berkisar antara 2,84 (biasa) hingga 3,80 (suka). Air seduhan teh herbal bubuk daun afrika yang diolah dengan metode A (pengukusan dan pengeringan) dan metode D (pengukusan dan penyangraian), paling disukai oleh panelis dengan masingmasing nilai 3,68 (suka) dan 3,80 (suka). Penerimaan keseluruhan teh herbal bubuk dipengaruhi oleh beberapa faktor seperti warna, aroma dan rasa.

\section{KESIMPULAN}

Berdasarkan hasil penelitian ini dapat disimpulkan bahwa metode pengolahan teh herbal bubuk daun afrika berpengaruh sangat nyata terhadap kadar air, total fenol, total flavonoid, aktivitas antioksidan, warna, serta uji sensoris warna, rasa, aroma dan berpengaruh nyata terhadap penerimaan keseluruhan serta berpengaruh tidak nyata terhadap kadar abu serta metode Pengukusan dan pengeringan mengahasikan teh herbal bubuk daun afrika dengan karakteristik fisik dan karakteristik sensoris terbaik dengan kadar air $6,41 \%$, kadar abu $5,27 \%$, total fenol 2,41 $\mathrm{mgGAE} / \mathrm{g}$, total flavonoid $2,65 \mathrm{mgQE} / \mathrm{g}$, aktivitas antioksidan 67,28\%, warna hijau muda, aroma sangat khas daun afrika, rasa sangat pahit, dan penerimaan keseluruhan suka.

\section{DAFTAR PUSTAKA}

Arpah, M. 1993. Pengawasan Mutu Pangan. Tarsito. Bandung

Association of Official Analytical Chemist (AOAC). 1995-2005. Official Methods of Analysis: AOACArlington

Bennett, L.E., H, Jegasothy., I, Konczak., dan D, Frank. 2011. Total polyphenolics and anti-oxidant properties of selected dried fruits and relationships to drying conditions. Journal of Functional Foods 3(2):115-124.

DOI: 10.1016/j.jff.2011.03.005.

Bernard, D., A.I, Kwabena., O.D, Osei., G.A, Daniel., S.A, Elom., dan A, Sandra. 2014. The effect of different drying methods on the phytochemicals and radical scavenging activity of Ceylon Cinnamon (Cinnamomum zeylanicum) plant parts. European Journal of Medicinal Plants 4(11):1324-1335. DOI:10.9734/EJMP/2014/11990.

Chan, E.W.C., Y.Y, Lim., S.K, Wong., K.K, Lim., S.P, Tan., F.S, Lianto., dan M.Y, Yong. 2009. Effects different drying methods on the antioxidant properties of leaves and tea of ginger species. Food 
Chemistry 113: 166-172. DOI:10.1016/j.foodchem.2008.07.090.

Chu, D.C., L.R. Juneja. 1997. General Chemical Composition of Green Tea and Its Infusion. Chemistry and Application of Green Tea, 13-22.

Damayanthi, E., C.M, Kusharto., Suprihartini., dan D, Rohdiana. 2008. Studi Kandungan Katekin Dan Turunannya Sebagai Antioksidan Alami Serta Karakteristik Organoleptik Produk Teh Murbei Dan Teh Camellia-Murbei. Media Gizi dan Keluarga 32(1):95-103.

Felicia, N. 2016. Pengaruh Ketuaan Daun dan Metode Pengolahan Terhadap Aktivitas Antioksidan Sertakarakteristik Sensoris Teh Herbal Bubuk Daun Alpukat (Persea Americana Mill.). Jurnal ITEPA. Universitas Udayana.

Grömer, T. 2009. The Secret of Japanese Tea. AIYA Europe GmbH, Jerman.

Hamidah, T., S. Kumalaningsih, dan I. A. Dewi. 2014. Pembuatan Ekstrak Oleoresin Daun Sirih Hijau (Piper betle L.) Sebagai Pengawet Alami (Kajian Suhu Dan Lama Waktu Ekstraksi). Skripsi. Universitas Brawijaya.

Hanani E., A, Mun'im., dan R, Sekarini. 2005. Identifikasi Senyawa Antioksidan dalam Spons Callyspongia sp. Dari kepulauan Seribu. Majalah Ilmu Kefarmasian Vol II No.3 Desember. 127-133

Hutching, J.B. 1999. Food colour and Appereance. Aspen Publisher.Inc.Marylan

Ibrahim. 2004. Assessment of the antibacterial activity of Vernonia amygdalina and Occimum gratissimum leaves on selected food borne pathogens. Journal of Enviremental Agricultural and Food Chemistry. 8 (11) : 1212-1218.

Ijeh II., K.K, Igwe. 2010. Effect of leaf aqueous extracts of Vernonia amygdalina Del. on contraction of mammary gland and uterus of guinea pig dams. J. Herbs Spices Med. Plants 16: in press

Irina, I., dan G. Mohamed. 2012. Biological Activities and Effects of Food Processing on Flavonoids as Phenolic Antioxidants. http://cdn.intechopen.com/pdfswm/26397.pdf. Diakses tanggal 23 Januari 2020.
Jeong, S. M., Kim, S. Y., Kim, D. R., Jo, S. C., Nam, K. C., Ahn, D. U., dan Lee, S. C. 2004. Effect of heat treatment on the antioxidant activity of extracts from citrus peels. Journal of agricultural and food chemistry, 52(11), 3389- 3393

Joko Nugroho W.K, Juliaty Lumbanbatu dan Sri Rahayoe, 2009, Pengaruh Suhu dan Lama Penyangraian terhadap Sifat FisikMekanis Biji Kopi Robusta. Jurnal Teknologi PERTETA, Mataram.

Kasih, A.L. 2007. Ekstraksi komponen antioksidan dan antibakteri biji lotus (Nelumbium nelumbo). Skripsi S1. Institut Pertanian Bogor. (tidak dipublikasikan).

Kusumaningrum, R., A. Supriadi, dan S. Hanggita. 2013. Karakteristik dan Mutu Teh Bunga Lotus (Nelumbo nucifera). Jurnal Teknologi Hasil Perikanan 2(1):921.

Kosinska, A., dan W. Andlauer. 2014. Antioxidant Capacity of Tea: Effect of Processing and Storage. Didalam Processing and Impact on Antioxidants in Beverages. V.R. Preedy (Ed.). Academic Press, Massachusetts. p. 109-120.

Laelasari, W. 2016. Kajian Karakteristik Seduhan Teh Herbal Dari Daun Murbei (Morus Sp) Yang Diproses Dengan Metode Pengolahan Dan Suhu Pengeringan Yang Berbeda. Skripsi. Fakultas Teknik. Universitas Pasundan.

Lenny, S. 2006. Senyawa Flavonoida, Fenilpropanoida dan Alkaloida. http://repository.usu.ac.id/bitstream/1234 56789/1842/3/06003489.pdf.txt. Diakses tanggal 23 Januari 2020Liliana, W. 2005. Kajian proses pembuatan teh herbal seledri (Apium graveolens L.). Skripsi S1. Institut Pertanian Bogor.

Marjoni, M.R., Afrinaldi dan A. D. Novita. 2015. Kandungan Total Fenol dan Aktivitas Antioksidan Ekstrak Air Daun Kersen (Muntingia calabura L.). Jurnal Kedokteran Yasri 23 (3) : 187-196.

Nakiboglu, M., R.O. Urek, H.A., dan Kayali, L. Tarhan. 2007. Antioxidant Capacities of Endemic Sideritis Sipylea and Origanum Sipyleum From Turkey. Food Chemistry 104(2):630-635.

Nasution, M.Z dan Wachyuddin. 1975. Pengolahan Teh. Fatemeta-IPB, Bogor 
Mahmood, T., N. Akhtar, dan B.A. Khan. 2010. The Morphology, Characteristics, and Medicinal Properties of Camellia sinensis' Tea. Journal of Medicinal Plants Research 4(19): 2028-2033.

Manohan, D., dan W.C. Wai. 2012. Characterization of Polyphenol Oxidase in Sweet Potato (Ipomoea Batatas (L.)).Journal for The Advancement of Science \& Arts 3(1):2129-2135.

Meilgaard, M., G. V. Civille dan B. T. Carr. 2000. Sensory Evaluation Techniques. Boca Raton. CRC Press. Florida.

Pramono, S. 2006. Penanganan Pasca Panen Dan Pengaruhnya Terhadap Efek Terapi Obat Alami. Prosiding Seminar Nasional Tumbuhan Obat Indonesia XXXVII, Bogor

Preedy, V.R. 2013. Tea In Health and Disease Prevention. Academic Press, Massachusetts.

Pujianingsih, D., S, Raharjo., Y, Marsono., dan U, Santoso. 2010. Pengaruh Blansing Terhadap Aktivitas Antioksidan, Kadar Fenol, Flavonoid, dan Tanin Terkondensasi Kunir Putih (Curcuma mangga Val.). Agritech Vol 30, No 3.

Rahman A. Riyanto dan Utari. 2006. Aktivitas Antioksidan, Kandungan Fenolat Total dan Kandungan Flavonoid Total Ekstrak Etil Asetat Buah Mengkudu Serta FrasiFraksinya. Majalah Farmasi Indonesia. 17:137-13

Ravikumar, C. (2014). Review on herbal teas. Journal Pharmaceutical Science \& Research 6(5): 236-238

Roni, M. A. 2008. Formulasi minuman herbal instan antioksidan dari campuran teh hijau (Camellia sinensis), Pegagan (Centella asiatica), dan daun jeruk purut (Cytus hystrix). Skripsi S1.Institut Pertanian Bogor.

Roy, M.K. 2006.Antioxodant methods on polyphenols and antioxidant activity of sweet potato leaves. Journal of Agricultural and Food Chemistry.103, 106-114.

Sakanaka S., Y, Tachibana., Okada., dan Yuki. 2005. Preparation and Antioxsidant Properties Of Extract of Japanese Persimo Leaf Tea. Food chemistry 89.569-575.

Sayuti, K., G, Taib., dan L, Hilma. 2010. Pengaruh perlakuan pendahuluan pada daun murbei (morus alba l) terhadap karakteristik minuman effervescent yang dihasilkan. Laporan Penelitian. Teknologi Hasil Pertanian. Universitas Andalas.

Sayekti, E. D., Asngad, A., dan Chalimah, S. 2016. Aktivitas Antioksidan Teh Kombinasi Daun Katuk Dan Daun Kelor Dengan Variasi Suhu Pengeringan (Doctoral dissertation, Universitas Muhammadiyah Surakarta).

Susanti, D.Y. 2008. Efek Suhu Pengeringan Terhadap Kandungan Fenolik dan Kandungan Katekin Teh Kombinasi

Daun Katuk dan Daun Kelor Dengan Variasi Suhu Pengeringan. Universitas Muhammadiyah Surakarta.

Thai Agricultural Standard (Tas 3000-2009). Mulberry Tea. Ministry Of Agriculture And Cooperatives. Bangkok

Topuz, A., C. Dincer, M., Torun, I. Tontul, H.S. Nadeem, A. Haznedar, F. dan Özdemir. 2014. Physicochemical Properties of Turkish Green Tea Powder: Effects of Shooting period, Shading, and Clone. Turkish Journal of Agriculture and Forestry 38:233-241.

Winarno, F. G. 2004. Kimia Pangan dan Gizi. PT Gramedia Pustaka Utama. Jakarta.

Winarsi, H. 2007. Antioksidan Alami dan Radikal Bebas. Penerbit Kanisius, Yogyakarta.

Yondra, A.D., C. Jose, dan H.Y. Teruna. 2014. Total Fenolik, Flavonoid Serta Aktivitas Antioksidan Ekstrak N-Heksana, Diklorometan Dan Metanol Amaranthus spinosus L Em5-Bawang Putih. JOM FMIPA 1(2): 359-369.

Yulianto, M.E., D, Ariwibowo., H, Arifan., F.S, Kusumayanti., dan Nugraheni, Senin. 2006. Model Perpindahan Massa Proses Steaming Inaktivasi Enzim Polifenol Oksidase dalam Pengolahan Teh Hijau. Gema Teknologi 15(1):25-30. 